\title{
A critical analysis of social innovation: A qualitative exploration of a religious organisation
}

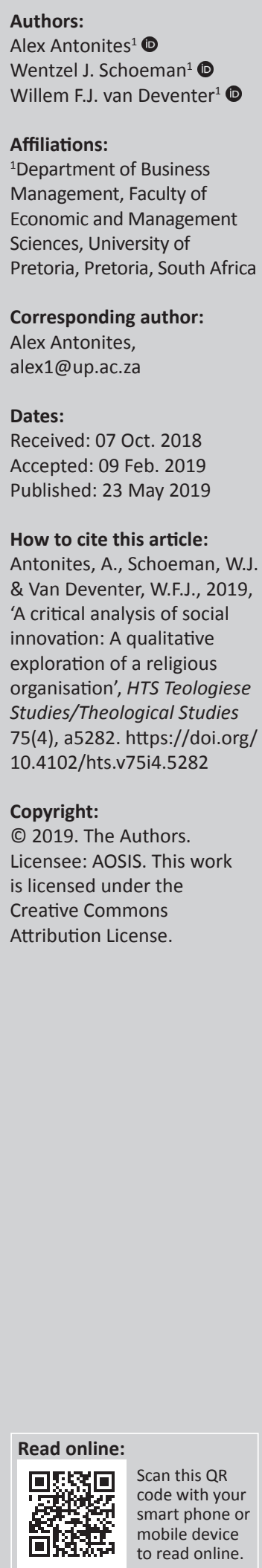

New challenges are constantly emerging in the social sector in South Africa. Various social (non-profit) organisations are developing new and innovative ways to accommodate these challenges and to meet social needs. The aim of this research article is to measure the current social innovation capacity of the Dutch Reformed Church (DR Church), with reference to innovation capabilities, to determine at what level the church is meeting new social needs. Semi-structured interviews were conducted to collect data from six different congregations and a governing body in the Pretoria area, South Africa, was included. Twelve participants were interviewed between August and October 2017. The participants, consisting of ministers and board members, each held a management position. The social innovation capacity measurement of the DR Church showed that the organisation was successfully developing new ways to serve as a social agent in society. There are obstacles that prohibit the DR Church from developing new innovative ways to meet the social needs of its society, for example, entrepreneurial, developmental and leadership change capacities. Recommendations are made to maximise social innovation capacity of the managers (ministers and board members).

Keywords: Innovation capacity; Innovation capabilities; Social entrepreneurship; Social innovation; Social impact.

\section{Introduction}

In recent times, governments and non-profit organisations have recognised the social innovative value that social enterprises contribute to society (Biggeri, Testi \& Bellucci 2017:1). Between 2000 and 2010, the membership of the Dutch Reformed Church (DR Church) diminished by more than 14\% (Schoeman 2014:3). The Biblical principle of an organisational church focusses on proclamation, transformation and service to the community (Daman 2006:19).

The DR Church plays an important role in the social environment of South Africa. Without adequate membership, this specific organisation will not be able to continue the social work that it is currently conducting. The DR Church will need to shift its focus from established patterns to new patterns (Nederduitse Gereformeerde Kerke 2015:5; Niemandt 2007:12). Dees (1998:1) defines social entrepreneurship as the passion of a social mission with a business-like mindset. According to Peredo and McLean (2006:1), social entrepreneurship is emerging as a way of dealing with complex social needs in an innovative manner. Social entrepreneurship aims to create shared value using innovative methods (Shaw \& De Bruin 2013:744). Mulgan (2006:146), Dees (1998:2, 5) and Peredo and McLean (2006:60,62) define social innovation as innovative services and activities where the goal of meeting a social need is the motivation.

It is a possibility that mainstream churches are losing their effectiveness as social agents. The total number of members has been steadily diminishing over the past decade, resulting in fewer resources being available to improve the social circumstances. The DR Church has not escaped this trend and is experiencing a similar problem (Nederduitse Gereformeerde Kerke 2015:5).

The aim of this research paper was to measure the current social innovation capacity of the DR Church to determine the level at which the church is meeting the demand for new social needs. Capacity in the context of this study encapsulates both human resources (e.g. knowledge or networking) and capital (e.g. financial or other tangible/infrastructural resources).

The following research questions served as a guide for the research project:

- What is the current social innovation capacity of the DR Church with reference to its innovation capabilities? 
- What internal and external factors influence the social innovation capacity of the DR Church?

- What prevalent issues exist that prohibit social innovation in the DR Church?

According to Van Wyk (2015a:3), the DR Church conducts a survey every 5 years, called The Church Mirror, to identify certain trends in the organisation. Mouton (2015:7) specifies that The Church Mirror includes a section on innovation. It also interprets various statistics. The number of members of the DR Church who believe that the denomination is innovative has risen from $25 \%$ in 2010 to $31.3 \%$ in 2014 . The Church Mirror is a quantitative survey of those who attend church on a regular basis. The findings are based on a standard questionnaire and random sampling (Schoeman 2011:474). The above-mentioned statistics indicate that the members of the DR Church are under the impression that innovation is increasing within the DR Church.

Membership of the DR Church is in gradual decline (Nederduitse Gereformeerde Kerke 2015:5), which concurrently exerts a negative effect on outreach to the communities (Van Wyk 2015b:11). Between 1972 and 2010, the membership of the DR Church decreased by more than 500000 members (Schoeman 2014:5).

The purpose of this study was to investigate and analyse the social innovation capacity of the DR Church as a social entrepreneurial agent in its environment. Dees (1998:1) defines social entrepreneurship as the passion of a social mission with a business-like mindset. According to Peredo and McLean (2006:1), social entrepreneurship is emerging as a way of dealing with complex social needs in an innovative manner. Social entrepreneurship aims to create shared value using innovative methods (Shaw \& De Bruin 2013:744).

Mulgan (2006:146), Dees (1998:2, 5) and Peredo and McLean $(2006: 60,62)$ define social innovation as innovative services and activities where the goal of meeting a social need is the motivation. Dees (1998:2) states that a social entrepreneur always searches for new ways to take hold of an opportunity to serve as change agents in society and the economy. However, social change is often confronted with resistance (Newth \& Woods 2014:5). Drucker (2014:168) mentioned the importance of the public service sector and noted the fast growth in the not-for-profit sector. This sector consists of social innovators who exploit opportunities by finding new ways to meet the social needs in society.

Bielefeld and Cleveland (2013:446) define a faith-based organisation (FBO) as an organisation that provides social services together with an expression of religion in some form. Baumann (2014:113) states that the study of FBOs is dynamically related to religion, the civil society and the state. It is thus appropriate to view FBOs as social organisations.

Semi-structured interviews with 12 clergy and board members were conducted from various congregations of the DR Church of Pretoria, South Africa. The aim was to measure the state of the social innovation capacity according to the three-point measurement method created and tested by Forsman (2011). For this study, the social impact of the DR Church was explored according to social innovation measures within the context of social entrepreneurship. A desktop review was conducted on social innovation and social entrepreneurship based on the systematic review advanced by Phillips et al. (2015:1).

In the current chaotic and complex world, not-for-profit organisations have to look at innovative ways to sustain a strong social impact. This includes social organisations that rely on their members to engage in or contribute to various community projects. This study contributes to both the academic and applied (organisational) spheres regarding social innovation in the DR Church as well as the social impact that not-for-profit organisations have in South Africa.

This research study measured the social innovative capacity within the DR Church (as briefly defined) using a qualitative research design. Recommendations have been made regarding how the DR Church could improve or accelerate the social innovation process to meet the needs of the existing members and the community it reaches out to. The literature explores the various definitions of social entrepreneurship and social innovation.

\section{Literature review}

\section{The social entrepreneur}

\section{Introduction}

Pirson (2015:2) states that social entrepreneurship attempts to make a positive difference in the world and use intellect to drive meaningful action. Choi and Majumdar (2014:372) regard social entrepreneurship as a cluster concept. This concept is illustrated in Figure 1 where the four smaller circles representing the social entrepreneur, the social entrepreneurial organisation, market orientation and social innovation are surrounded by the larger concept of social value. Choi and Majumdar (2014:372) regard these five fields as the cluster concept of social entrepreneurship. This concept forms the base of the literature review.

\section{Social entrepreneurship}

Kickul and Lyons (2012:19) refer to various definitions of social entrepreneurship. It is, however, important to recognise that social entrepreneurship is a continuous process. Any type of organisation should identify an innovation deficit (an area that requires new solutions to new or existing problems) to create social value by implementing the social process.

According to Newth and Woods (2014:1), Joseph A. Schumpeter identified the entrepreneur as an economic agent who applies change through innovation. Change is initiated by combining different disciplines and fields of study in order to create social value. Schumpeter (1934:3) identified social entrepreneurship as an academic field in the early 19 th century. 


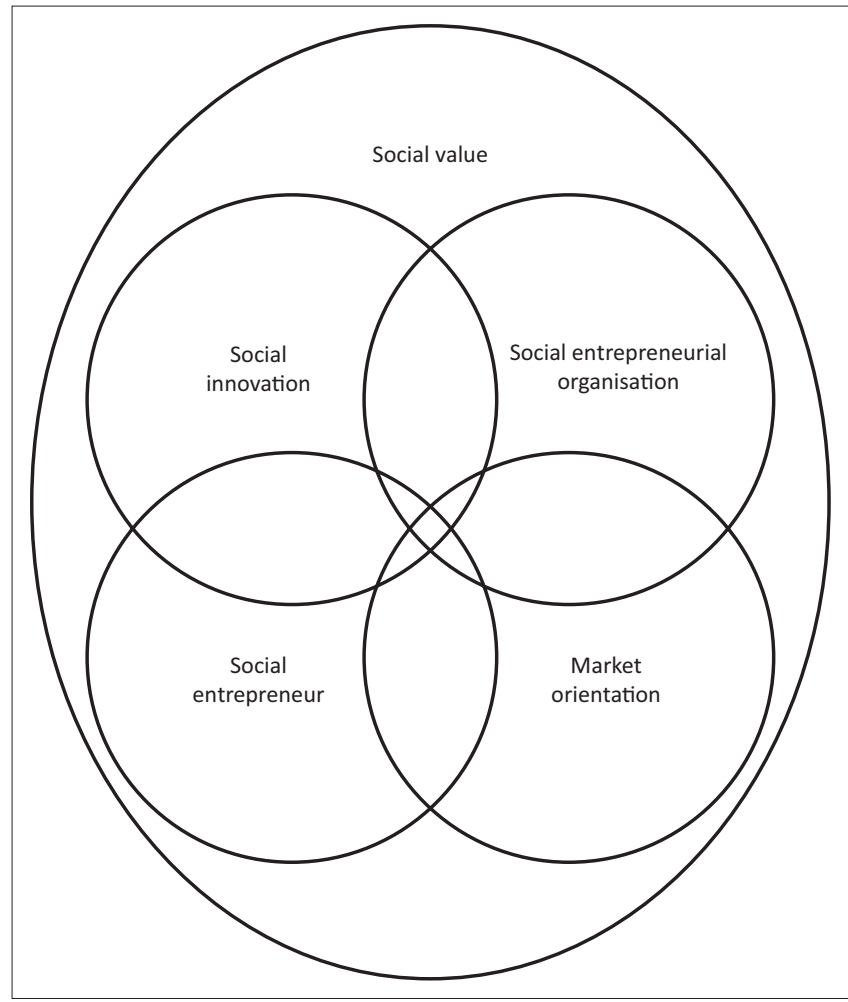

Source: Adapted from Choi, N. \& Majumdar, S., 2014, 'Social entrepreneurship as an essentially contested concept: Opening a new avenue for systematic future research', Journal of Business Venturing 29(3), 363-376. https://doi.org/10.1016/j.jbusvent.2013.05.001

FIGURE 1: Social entrepreneurship cluster concept.

According to Choi and Majumdar (2014:372), the academic field of social entrepreneurship is complex in nature as it comprises various sub-fields. As mentioned earlier, Choi and Majumdar (2014:372) identified the following five different sub-fields of social entrepreneurship:

1. social value creation

2. the social entrepreneur

3. the social enterprise

4. market orientation

5. social innovation.

The goal of these different sub-fields is set for academic purposes. This allows the researcher to state which subfield(s) of social entrepreneurship are being researched.

As stated, this study focusses on the social enterprise as a contributor of social value and social innovation as a means to find new ways to existing challenges in the specific organisation, the DR Church.

Newth and Woods (2014:3) state that the academic community does not have consensus concerning the definition of social entrepreneurship. Thus, social entrepreneurship must rather be studied as a process in a specific sub-field. The various subfields of social entrepreneurship make it difficult to reach a unified definition of social entrepreneurship. Newth and Woods (2014:4) state that the contribution of Schumpeter (1934:3) to the academic field of social entrepreneurship as a process of combining different fields of study to create social value still forms the basis of social entrepreneurship today.
Zahra et al. (2009:519) attempted to define social entrepreneurship using Schumpeter's explanation of 1934 as a basis: 'The activities and processes undertaken to discover, define, and exploit opportunities in order to enhance social wealth by creating new ventures or managing existing organisations in an innovative manner'.

Phillips et al. (2015:442) state that social entrepreneurship identifies and attempts to resolve a social problem. Phillips et al. (2015:442) add that the social enterprise identifies its own social requirements that need to be met. These social requirements are usually communicated in the form of a social mission statement or an opportunity recognised in society.

\section{The social enterprise}

Shaw and De Bruin (2013:741) argue that the debate regarding a definition of a social enterprise is now saturated. Thus, a social enterprise can be defined as an enterprise that engages in mainstream activities, processes and behaviour. This could include for-profit activities like trading and manufacturing. A social enterprise can be identified by recognising how surpluses are used.

Choi and Majumdar (2014:374) state that the social enterprise has many facets, including special funding, collaboration with various social role players, various laws regulating them, various organisational structures and various countries. The social enterprise is an integral part and a sub-field of study in social entrepreneurship. The social value creation process renders the social enterprise part of the cluster concept of social entrepreneurship. Thus, it would be impossible to research social entrepreneurship without analysing the social enterprise in the process.

\section{Social entrepreneurial role players}

Phillips et al. (2015:442) state that the traditional view of a social entrepreneur is a single person who wants to bring change to the world. This, however, is not the case. According to Kickul and Bacq (2012:58), social business planning has a multi-stakeholder approach. If a social entrepreneur wants to be effective, he or she must innovate. An integral part of innovation is to form partnerships or hire employees. Phillips et al. (2015:442) note that networking is important for the social innovative process.

The social entrepreneur and team must manage relationships with various stakeholders. Kickul and Bacq (2012:60) identified five stakeholder groups that the social entrepreneurial business must consider:

1. Funders and management teams: Mapping abilities of the leading managers in the planning process is important for the execution phase.

2. End markets and other beneficiaries: The identified markets (to which the business will add social value) are often unable or unwilling to pay for the specific goods or services provided by the social business. Resource strategies should therefore be considered in the planning process. 
3. Employees: In a traditional, for-profit business, employees are viewed as a cost connected to a specific resource provided. The employees of a social business are not only viewed as a fixed component of the cost structure but also as a core contributor to creative and innovative thinking.

4. Context, competitors and other partners: The new social business must often plan and form partnerships with its competitors and partners to create social value more effectively.

5. Resource providers: The social business must plan and identify their resource providers.

\section{Social innovation}

Mulgan (2006:146) defines social innovation as 'innovative activities and services that are motivated by the goal of meeting a social need'. Phillips et al. (2015:430) note that for-profit organisations aim to create social value through their corporate social responsibility programme. For-profit organisations could also have a goal to create social value through activities, services and products.

De Bassi Padilha, Cziulik and de Camargo Beltrão (2017:2) stated that innovation as a capability in an organisation is a critical success factor in organisational growth. They define innovation as the implementation of an output (product or service, new and improved service) as a process. Innovation includes the application of knowledge that is new to the organisation but not necessarily new to the world.

Schumpeter (1934:4) described social innovation as an economic development process in a 'non-priced' or not-forprofit environment. Newth and Woods (2014:3) state that the academic field of social entrepreneurship and social innovation has developed considerably since the time of Schumpeter's work in the early 20th century.

The term social innovation refers to private corporations operating in the social sector. They explore not only new markets but also increased ways in which the community can benefit. According to Phillips et al. (2015), social innovation can be described as:

An intervention initiated by social actors to respond to an aspiration, to meet specific needs, to offer a solution, or to take advantage of an opportunity for action in order to modify social relations, transform a framework for action, or propose new cultural orientations. (p. 447)

Niemandt (2007:52) describes social innovators as persons who are prepared to do what is necessary to adapt to new conditions and likewise perpetuated by a systems approach.

Choi and Majumdar (2014:368) state that social innovation is a sub-field and an integral part of social entrepreneurship. Social entrepreneurs employ social innovation to continuously innovate to solve problems in society. Social entrepreneurs are expected to bring sustainable social change in society and are therefore referred to as social innovators. Choi and
Majumdar (2014:368) clearly show that social innovation is a sub-field of social entrepreneurship.

Martinez et al. (2017:1) stated that social innovation is best understood as a process that relies on the social dynamics between businesses and individuals. Economic activity traditionally views human resources as a category wherein individuals are used to create economic value (particularly capitalistic). The concept of social innovation aims to create value in its fullest sense (social value). According to Phillips et al. (2015:430), social value aims to fulfil a social need or resolve a social problem as opposed to shareholder wealth in a for-profit organisation. Tracey and Scott (2017:55) reason that social innovation is an umbrella concept that combines organisational activities that are implemented with the purpose to aid the resolution of problems in societies.

Schultz (2013:12) describes deliberate disruptive design as social innovation that gives the simplest explanation for social entrepreneurship. This corresponds with Choi and Majumdar (2014:372) describing social innovation as a sub-field of social entrepreneurship. The deliberate disruptive design process can be understood as follows:

- Deliberate: The social entrepreneur is on a deliberate mission (as opposed to a random mission) to facilitate change in the social environment.

- Disruptive: Disruptive innovation brings a competitive advantage to the social environment.

- Design: Social innovation aims to cross the traditional boundaries between not-for-profit, for-profit and public organisations to create social value.

Scofield (2011:208) proposes innovation standardisation as a concept to identify when to reinvent a system, as opposed to adapting the same system to solve problems in a changing environment. Newth and Woods (2014:4) describe social innovation as a process that combines various resources to create new combinations to address social problems. Social entrepreneurship brings new combinations to the market. Social innovation must be coupled with the social enterprise, with the social entrepreneur taking the new product or service to the market. New product or service offerings in the context of innovation could contribute to higher operational efficiencies, speed and reduced cost. In addition to the material advantages, a key advantage resonates with enhanced social impact.

\section{Innovation capacity}

The continuous development of capabilities and resources within an organisation with the aim of exploring and exploiting new opportunities to meet social needs is defined as the innovation capacity of an organisation (Szeto 2000; Tsai \& Liao 2017:3). Kirner, Kinkel and Jaeger (2009) regard innovation capacity as the same as formal research and development (R\&D) activities of organisations. However, within small organisations, innovations are the result of daily activities such as member collaboration regarding the 
optimisation of processes rather than formal R\&D (HirschKreinsen 2008). Innovation development is not the main objective of those involved in innovation capacity development, but rather the individuals who collaborate with members (Forsman 2011:740).

Forsman (2011) studied the degree of innovation capacity of small organisations by examining their R\&D investments, the degree of innovation capabilities and the external innovation input received through networking. Innovation capabilities were assessed by grading seven defined dimensions on a three-point scale. Lastly, external input was assessed based on whether the impact of networking was viewed as positive, negative or had no impact.

\section{Key role of transformational leadership in social entrepreneurship}

As mentioned, according to Forsman (2011:749), the capability to implement change is a key factor in measuring innovation capacity. This includes the capability to quickly implement change. Therefore, change management and transformational leadership constitute an integral part of social entrepreneurship.

According to Phillips et al. (2015:447), transformation of an existing framework is always part of the social innovative process. Kickul and Bacq (2012:114) explain that the fields of transformational leadership and social innovation overlap in many areas. Khalili (2016) reflects on empirical evidence that transformational leadership enhances creative thinking, innovation given a perceptual experience of a supportive climate for innovation. The findings of Jaiswal and Dhar (2015) confirm the latter by displaying a direct link between this leadership style and the existence of a climate for innovative behaviour. An even deeper investigation results in evidence that transformation leadership contributes more to team innovation than individual innovation (Li, Mitchell \& Boyle 2016). The lens of this study relates to the social entrepreneurial organisation with much to learn from the latter findings in terms of specifically innovation and innovation management.

As stated, Schultz (2013:14) explains the social entrepreneurial process as a deliberate disruptive design process. This relates to the four elements of transformational leadership as stated by Kickul and Bacq (2012:114). Incremental innovation exists as opposed to deliberate disruptive design. According to Norman and Verganti (2014:4), incremental product innovation occurs when small changes in a product are made to meet new standards. This could include new technological advances to meet current needs. In social innovation, small changes in a current social offering can be incrementally made to meet new needs. The contextual nature of the unit of analysis, the DR Church, asks for innovative approaches to either survive or grow in line with the needs of their key stakeholders' needs coupled with higher social impact. Innovation per se is a process that directly aligns value-tomember (user) requirements, new areas of development and also creates incremental or leapfrog offerings to enhance social change (e.g. new technological platforms to distribute the core offering of a church, with reference to new generations).

\section{Innovation deficits}

Mulgan (2006:147) identifies an innovation deficit as the gap between current provision and existing needs. The innovation deficits illustrate topics or areas where new ways must be found and implemented (innovation) to address global common needs (social needs).

\section{Measuring social impact}

According to Trelstad (2008:107), the social entrepreneur may have some difficult challenges to measure social impact. Measuring social impact is made difficult by two factors (Kickul \& Lyons 2012:177; Trelstad 2008:107; Tuan 2008:6-7):

- A general lack of maturity in measuring social impact, as measurement methods are not well developed.

- Social organisations differ greatly in size and purpose.

\section{Determining degree of innovation capacity}

According to Forsman (2011:749), innovation capacity can be measured using seven elements.

The following seven elements closely relate to the research questions used in this study to determine the degree of social innovation capacity in the DR Church:

- capabilities for knowledge exploitation

- entrepreneurial capabilities (opportunity recognition)

- risk management capabilities

- networking capabilities

- development capabilities (use internally generated ideas)

- change management capabilities

- market and customer knowledge (non-profit industry knowledge and R\&D).

\section{Evaluating change (social innovation)}

Tracey and Stott (2017:51) suggest that social innovation is as old as time itself, although when reading the literature one may believe it is a new concept. Social innovation in general is defined as the implementation of new concepts to solve social problems, where the innovator is not the sole beneficiary of the result.

Schultz (2013:67) states that a social entrepreneur is constantly being evaluated in an everchanging complex environment. A social entrepreneur must adapt to the changing complex environment. Therefore, the measurement of a project should not be seen as static, as new and better ways may improve the desired outcomes (social innovation).

\section{Social entrepreneurship and social innovation in the Dutch Reformed Church}

\section{Background}

Du Toit et al. (2002:3) state that the DR Church, as an institution, has changed considerably during the last quarter 
of the previous century. Du Toit et al. (2002:4) refer to the negative association of the DR Church with 'separate development' or 'apartheid' as a reason for less sympathy amongst the democratically elected politicians. With the 'New South Africa' being more open to freedom of religion, the government cannot have more sympathy for a specific group, church or religion.

The influence that this religious institution has in South African politics has thus been minimised since 1994. As a result, this has reduced the resources available for the DR Church to use for social impact.

The DR Church has a dynamic history of change. Du Toit et al. (2002:xvi) constructed a timeline and identified a few important events that have impacted the DR Church and how it responded to these events.

Examples of such events are the Cottesloe meeting in 1960 (held in Cottesloe in Johannesburg), which stated that the wealth of a country should be shared by all of its residents (Du Toit et al. 2002:56). In 1982, a document entitled 'Kerk en Samelewing' [Church and Society] stated that members of the DR Church could be of any race (Du Toit et al. 2002:83). In 1990, at a meeting in Rustenburg without any political influence, entitled 'Die Rustenburgberaad', labelled 'separate development' or 'apartheid' as a sin (Du Toit et al. 2002:105). Niemandt (2007:84) states that congregations should determine what their specific calling is in their society. The congregation should then plan and execute the identified community work.

\section{Transformational leadership in the Dutch Reformed Church}

Niemandt (2007:52) states that change starts with innovation. It is the innovator that innovates when he/she adapts to the everchanging environment. Innovation is a process that can occur in a complex environment (Schultz 2013:69). Mouton (2015:7) lists three different types of transformational leadership that are applicable in the DR Church, namely:

- Technical leadership: The ability to perform everyday tasks.

- Transactional leadership: Leadership where others are influenced.

- Transformational leadership: Leading a process of identity, cultural, missional and operating change.

\section{Measuring social innovation or transformation in a church}

According to Daman (2006:137), transformational leadership is a Biblical imperative of any church. The church must engage the community at every level in order to bring change to that community. The purpose of any church is to transform its community within moral, social and spiritual frameworks. While the social benefits to the community can be monetised (Kickul \& Lyons 2012:182), the moral and spiritual changes in a society can be assessed using only non-monetary methods (Schultz 2013:69). In this study, the three items mentioned by Forsman (2011:749) were used to measure the degree of innovation capacity.

\section{Importance of the study}

As stated, the DR Church has changed considerably during the last quarter of the previous century. This indicates that the leadership within the DR Church is transformational in nature. As stated by Niemandt (2007:52), change begins with innovation.

In this study, the innovation capacity of the DR Church was measured to determine its current degree of innovation capacity. As evident in history, social innovation in the DR Church has played a critical role in the history of South Africa on various levels.

In South Africa, $62.3 \%$ of the population falls within the lower income bracket of earning less than R86 000 per annum. In the lower class, spending on food constitutes between $29 \%$ and $34 \%$ of the total expenditure, which will increase with the high inflation levels. Transport consumes between $11 \%$ and $12 \%$ of the lower-class income, with less than $2.5 \%$ being spent on education and other components, including medical aid, insurance and pension (Writer 2016). Not-for-profit organisations, such as the DR Church, could play a significant role in addressing the above-mentioned issues.

\section{Conclusion}

The DR Church was discussed as a social organisation that has changed (positively and negatively) over the past five decades. Diminishing membership (and resources) was discussed as a possible cause of a probable loss of social effectiveness of the organisation. The objective of this study was to measure the social innovation capacity of the DR Church. The method put forth by Forsman (2011:743) was selected to measure innovation capacity in a social context. This literature review explored the concepts of social entrepreneurship, innovation, social innovation and innovation capacity. As discussed, this organisation has contributed greatly to the social changes witnessed in South Africa, and it still has a role to play in the current and future South Africa.

\section{Methodology Research design}

The three research questions of this study focussed on the social innovation capacity of the DR Church. In this research study, face-to-face semi-structured interviews were held with board members of the DR Church in order to determine their opinions regarding the social innovation capacity, what internal and external factors influence the social innovation capacity, and the issues that prohibit social innovation capacity in the DR Church. The purpose for selecting a generic qualitative research design was to explore the multiple opinions of the board members of the DR Church with regard to the umbrella topic of social innovation capacity. The results of the study were interpreted along with the literature of other studies to determine whether a similar phenomenon of limited innovation capacity is present in the DR Church (Creswell \& Poth 2017:67). 


\section{Sampling}

The units of analyses for this research study comprised the multiple congregations and organisations of the DR Church in Pretoria. The DR Church consists of several homogenous congregations and organisations in Pretoria. Homogenous sampling was used for selecting participants. The participants had to know the DR Church as a denomination well in order to comprehend the current state of the organisation. The advantage of this sampling method is that the opinions of the participants could be compared more easily. A disadvantage was that not all of the participants fully comprehended the current state of the denomination owing to their limited experience. It was a requirement that the participants must be over the age of 18 years, having served on a DR Church board for more than 3 years. Table 1 summarises the sampling design that was followed for this research study.

\section{Data collection}

As mentioned, 12 face-to-face semi-structured interviews were conducted between August and October 2017, and the audio recordings were transcribed within 2 weeks after the interview by the researchers. The transcripts were then analysed using qualitative analysis methods. Elliott (2005:18) stated that interviews (including semi-structured interviews) are central to the social sciences and their data collection methods. The purpose of these conversations was to collect expert opinions in the form of textual data (transcriptions of conversations) that were analysed. Open-ended questions were used to provide the interviewee with the opportunity to express his or her opinion regarding a specific situation, the reason being that more data could be extracted from each participant as the population from which the empirical data was derived was small (Creswell 2014:157).

\section{Data analysis}

A thematic analysis approach was used to determine patterns formed in the data. The transcripts were coded and analysed by the use of a qualitative research analysis programme. The codes were linked to the research questions and themes and sub-themes were identified.

\section{Trustworthiness}

The trustworthiness of this study was ensured by using credibility and conformability strategies. The credibility of

\begin{tabular}{|c|c|c|}
\hline Sampling of: & Organisations & Individual participants \\
\hline $\begin{array}{l}\text { Main inclusion/exclusion } \\
\text { criteria }\end{array}$ & $\begin{array}{l}\text { The inclusion criterion } \\
\text { for organisations is that } \\
\text { the congregation } \\
\text { (individual organisation) } \\
\text { must form part of the } \\
\text { denomination of the } \\
\text { DR Church. }\end{array}$ & $\begin{array}{l}\text { The inclusion criteria for an } \\
\text { individual are that the person must } \\
\text { be a board member of a DR Church } \\
\text { in the Pretoria area; he/she must } \\
\text { be over } 18 \text { years of age; and he/ } \\
\text { she should have served as a board } \\
\text { member for more than } 3 \text { years. }\end{array}$ \\
\hline $\begin{array}{l}\text { Overall minimum target } \\
\text { sample size }\end{array}$ & 6 & 12 \\
\hline $\begin{array}{l}\text { Minimum target sample } \\
\text { size per participating } \\
\text { organisation }\end{array}$ & - & 1 \\
\hline $\begin{array}{l}\text { Sampling method(s) to } \\
\text { be used }\end{array}$ & Homogenous & Homogenous \\
\hline
\end{tabular}

the research study was supported by firstly gathering as much information as possible on the DR Church as an organisation. The DR Church was researched in detail in the literature review. Being familiar with the organisation was crucial in asking the correct questions in the semi-structured interviews. The data were also triangulated by means of sampling from different congregations within the DR Church. Interviewees were given the assurance that they would remain anonymous. Member checking was implemented as a last strategy to ensure that what the interviewee said and what the interviewer understood was congruent.

According to Lietz and Zayas (2010:197), a study must prove that the data and findings are clearly linked in order to reach confirmability. The first technique implemented to demonstrate confirmability was the use of open-ended questions. The semi-structured interview questions were formulated in a manner that would not lead the interviewee to a specific answer. Transcriptions and recordings were simultaneously read and listened to, respectively, in order to correctly understand and interpret the context in which a question was asked and answered. This ensured that interviews were also peer-reviewed by both members in the research team.

\section{Ethical considerations}

Ethical clearance was granted by the University of Pretoria's Research Ethical Committee on 18 August 2017. Before the interview, the interviewers explained that participation in this study was voluntary. The participants signed a consent form stating that they agree to participate in the research on condition that their identity would remain confidential.

\section{Findings}

In this section, the findings of this research are reported per research question. The seven-point measurement method created and tested by Forsman (2011) to test innovation capabilities identified the main and sub-themes necessary to measure the innovation capacity of the DR Church in the Pretoria area. The research questions are linked with the three-point measurement method in such a manner that innovation capacity within the involved organisation could be measured.

The degree of innovation capabilities (measured by the seven-dimension system) forms part of the three variables used to measure the degree of innovation capacity.

\section{Findings related to research question 1}

The first research question: What is the current social innovation capacity of the DR Church with reference to its innovation capabilities? (To determine the development capabilities of the organisation). The main themes included entrepreneurial capabilities and development capabilities. 


\section{Entrepreneurial capabilities}

The participants of the organisation displayed capabilities to not only recognise new opportunities but also to seize and develop them. Most of the participants said that opportunity recognition is a slow process in the organisation but that it does still exist. The participants referred to many opportunities in the region that were identified and seized. Examples of this include practical outreach programmes such as education programmes and giving handouts/ education to those living on the streets in the area. Local townships are also the destinations for many outreach programmes. This usually includes reaching out to those who are poor. Many participants said that listening to the needs of those living in the townships is important as they are not open to receiving handouts. Many of the participants referred to a book entitled: When Helping Hurts: How to Alleviate Poverty Without Hurting the Poor and Yourself (Corbett \& Fikkert 2014), mentioning that a community must be open to receiving help before helping can exert a positive impact.

\section{Development capabilities}

The participants of the organisation displayed developmental capabilities. They mentioned growth and cell groups that stimulate personal and member growth in the organisation. Other social events contribute to more people coming to the organisation, which might include dances (sokkies) and other events for the younger members. The organisation is experiencing personal and member growth with a family ministry, which includes groups for mothers, babies and married couples. Where resistance exists (in any form), the members and board members meet to talk, listen and reduce the friction caused by the resistance. The organisation is very sensitive to criticism.

Many of the participants indicated the importance of the music ministry. All of the participants have modernised their music in one way or another to fit their specific style. Modern songs can be stylised in a classical fashion in order to adapt to the style of a specific congregation.

\section{Findings related to research question 2}

The second research question: What internal and external factors influence the social innovation capacity of the DR Church? The main themes included capabilities for knowledge exploitation and networking.

\section{Capabilities for knowledge exploitation}

The participants of the organisation displayed strong capabilities to recognise, exploit and internalise new knowledge from external sources. The organisation believes that external knowledge is important. The participants referred to the training of ministers at an academic institution (university faculty) rather than a seminary. They also have philosophical and medical knowledge from the academic institution. The academic knowledge is then used in sermons and talks to reduce friction (exploited and internalised).
Participants also referred to popular sources such as magazines and the Internet as possible sources of external knowledge to be internalised. Many participants referred to their own census research before an outreach, as the local census of the government might be less reliable for the specific outreach programmes (external data used in programmes). Many participants referred to external books and programmes as external knowledge. Examples of the external programmes used are the Alpha and Strength Finder courses.

External technical knowledge is also identified and exploited internally, for example, the newest financial software, data projectors, websites and social media. The participants referred to ministers and board members who are keen to learn from other disciplines and experts. For example, many participants displayed an intent to learn more from the field of psychology. Members of the organisation are skilled in various disciplines; the organisation exploits and internalises these skills of these members very well.

Internalised skills of members are in the realms of finance, music, psychology, real-estate and information technology.

\section{Networking capabilities}

The participants of the organisation displayed strong capabilities to network. Participants referred to the different networks between academic fields. Theology is the primary field of study for the organisation, but other fields of study are incorporated with their experts in appropriate scientific conversation.

All participants were in favour of organisational (church) unity and stated that networking with other institutions is important. In a healthy situation, there are always first voices crying out against social injustices. The organisation listens to these voices and supports them in many cases. Examples of such cases include the organisation when it listened to voices crying out against the social injustices of apartheid. The organisation eventually joined forces with those who cried out. The participants mentioned that the organisation supports the voices crying out against the socio-economic injustices of the current government of South Africa. The organisation also participates in local (Pretoria area) social action such as the fees-must-fall movement. Participants reported that racism is a major issue, and that the organisation attempts to help the various parties not to increase the distance between races, but to rather build an understanding of one another.

Many participants said that it is the responsibility of the organisation to listen to the leaders from other organisations (churches) to simply attempt to understand their living context and to build relationships.

Leaders of the organisation displayed a need not to 'work for' other organisations (churches) but to 'work with' them. Certain participants said that reform celebrations cannot 
begin without respecting their brothers and sisters from other organisations (churches). This includes helping them with the resources that they do not have.

Participants referred to their own and other church denominations, saying that their relationship with the government is difficult, as the government regards the larger church community as a provider of unnecessary criticism.

Currently, there are limited to no existing networking capabilities within the government across this domain.

\section{Findings related to research question 3}

Research question 3: What prevalent issues exist that prohibit social innovation in the DR Church? The main themes included risk management capabilities and change management capabilities.

\section{Risk management capabilities}

Abilities for risk-taking and assessment: Most of the participants said that the denomination sometimes misses possible opportunities, because it is too scared of the risk attached to certain opportunities. The ministers and board members also realise that they make decisions on behalf of the denomination and its members, resulting in decisionmakers being more risk-minded.

All the participants said that the denomination does not easily take high financial risks. The use of the facilities also poses a major risk, which results in financial implications and various risks. The organisation does not want to abuse its facilities.

Social issues were also identified by many participants as a potential risk, with change being the main risk in whatever form. The so-called gay debate (to allow LGBTQ+ persons as ministers) and the Belhar debate (a change in the confession documents) were used as examples of risk factors by many of the participants. The risk included losing members when change happens, regardless of the direction of the change. The risk of losing members also results in financial losses. Most of the participants said that it is more important to make the correct decision (moral and Biblical) than to make an incorrect decision to please certain people or parties. Most of the participants mentioned that they are very willing to make the correct decision and to accept the resulting risk. The risk is handled in such a manner that the organisation's changed position on a specific subject is discussed and communicated to all involved members and parties.

A major risk identified by some of the participants was that there were uninformed members and non-members with outdated views who did not understand the current changes and decisions. This would usually result in negative critique (risk). Participants said that such individuals (risks) should participate in discussions and must be informed of current reasons for social change. Conversation is the preferred way to handle such risks of change. The denomination is willing to accept the risk of conversations.

Participants also mentioned that the environment is the responsibility of all people and the risk needs to be taken seriously. Environmental friendliness is a topic on which the denomination conducts discussions.

To speak out against racism is also a possible risk for the organisation as the organisation initially supported apartheid, but later, in the 1980s, changed to radically oppose it. This was a change-related risk that the organisation took and is still willing to accept.

The participants said that the younger generations forced them to be more open to risk-taking as they require new and innovative ways of thinking. The younger generations can also promise much but deliver nothing, as their dreams mostly remain dreams. Most participants said that the younger generation also forces willingness to accept new risks and refers to change in society and music as topics of discussion.

The participants were confident that many skilled members were attending to different risks, as different committees are responsible for the accompanied risks. The financial, realestate, human-resources, safety and change committees are a few examples.

\section{Change management capabilities}

Many participants said that the denomination has a slow decision-making system, but that this had recently improved. Participants stated that many congregations had changed to a more efficient and quicker decision-making system over the past few years, resulting in a local management system (concerning the church board) that is able to respond to change more quickly. Most participants, however, mentioned that the response of the larger system of the denomination is still slow, referring to the gay and Belhar debates (as previously discussed).

\section{Findings related to research question 4}

General question: Current life cycle of the organisation?

\section{Market and member (customer) knowledge (knowledge regarding the life cycle of the organisation)}

The members and those receiving social assistance from the denomination is equated to customers in a commercial context, as they are the receivers of the services of the denomination. The life cycle of the denomination paints a direct picture of the members and those receiving social assistance.

All the participants placed the denomination (as an organisation) in a phase of maturity or growth. Some participants mentioned that the organisations have witnessed 
a decline in the past but that maturity is the current phase. The participants stated that maturity or growth refers to an organisational efficiency and number of members. Some participants said that their financial position is weakening and links it with the economic climate.

\section{Conclusion}

\section{Summary of findings and theoretical implications}

The aim of this research paper was to measure the current social innovation capacity of the DR Church to determine the level at which the church is meeting new social needs. Social innovation capacity was measured by the three variables that Forsman (2011) created and tested. A variable tested the degree of innovation capability (measured by the seven-dimension system). Each variable is now discussed in a social context.

\section{Research and development investment}

Most of the participants said that R\&D is the responsibility of the ministers and not necessarily the board members. Of the group interviewed, the average R\&D time spent per week is 8.8 hours (total average), while the ministers in the group interviewed averaged 12.2 hours (total average). The organisation involved operates within the social sector in South Africa. There are no existing comparative studies that have measured time spent on R\&D within the same context. In contrast, Pinelli, Barclay and Kennedy (1996) reported that The National Aeronautics and Space Administration aerospace scientists and engineers spend 12.1 hours (total average) on producing written material and 11.6 hours (total average) communicating information. Ministers in the DR Church show a strong tendency to invest time in R\&D.

\section{The degree of innovation capabilities}

The degree of innovation capabilities was measured according to the seven-point measurement system created and tested by Forsman (2011:794). The results of the findings were as follows:

- Capabilities for knowledge exploitation: The organisation believes that external knowledge is important and displays a strong tendency to recognise, internalise and exploit it in new innovations. The organisation gives the impression that the origin of most innovations is generated externally.

- Entrepreneurial capabilities: The organisation displayed average entrepreneurial capabilities as it recognises new opportunities and seizes some of them, but exploiting new opportunities is a slow process that takes much time and effort.

- Risk management capabilities: The organisation is unwilling to accept new financial risks, while it hesitates to take new risks in a social context as those risks could result in an outflux of members (donors), which would result in financial loss. The organisation displayed strong tendencies to identify risks as members with various skills attend to the handling of risks, while most risks that the organisation accepts are forced by circumstances. The organisation thus has to be willing to accept certain risks.

- Networking capabilities: The organisation displayed strong capabilities to network and to collaborate with other denominations. The organisation views networking as a critical and mandatory part of its work.

- Development capabilities: The organisation displayed average capabilities to develop as new ways are sometimes implemented to grow on a small scale.

- Change management capabilities: The various congregations within the organisation are improving their system to increase the speed of decision-making, but the larger denominational system is currently slow in this aspect.

- Market and member (customer) knowledge (knowledge regarding the life cycle of the organisation): The organisation displayed a tendency to be in the maturity phase or growth phase after maturity.

\section{External input into innovation development through networking}

External input through networking into innovation can be measured by identifying positive impact, no impact and negative impact. No participant mentioned negative impact on innovation through networking, while a few referred to examples where networking resulted in no impact (decided against the accompanied innovation). All the participants reported many positive impacts exerted on innovation through networking.

It is the finding of this study that, overall, the networking impact of innovation on the DR Church is positive.

The variable of external input into innovation development through networking was thus reported positively by most of the participants on many accounts.

\section{Social innovation capacity measurement}

According to the three variables advanced by Forsman (2011), it can be concluded that the DR Church as an organisation possesses strong and average elements of capacity for innovation, as discussed.

\section{Discussion}

\section{Research and development investment}

During this research, it became clear that the amount of time spent on R\&D by the ministers in the organisation is quite extensive (as calculated). It is significant that both the ministers and board members said that the R\&D responsibility lies with the ministers only. It can be recommended that all persons in management positions (ministers and board members) should engage in the R\&D process, which could include reading similar books, for example. Advance research platforms are available to continuously assess the micro, meso and macro environment to reactively and proactively address change and needs. A deliberate programme should 
be established within the managerial structure of the entity to formally address the latter.

\section{The degree of innovation capabilities}

The DR Church displayed strong innovation capabilities in three dimensions, namely: capabilities regarding knowledge exploitation, networking and market and member (customer) knowledge. The DR Church displayed average innovation capabilities in four dimensions (on which the organisation could improve in future), namely: entrepreneurial, risk management, development and change management capabilities.

Throughout this study, it became clear that those in management positions (ministers and board members) of the DR Church could improve on these aspects. An entrepreneurial/intrapreneurial mindset should be applied within the managerial sphere to continuously identify opportunities towards finding sustainable outputs (without negating the core offering of the church).

\section{External input into innovation development through networking}

This research reveals that the organisation displays a strong capability to experience a positive influence on innovation by networks. It is recommended that the organisation continues to enjoy a positive effect by networks but also to exploit networks to gain more positive influences. Networking, again, is an entrepreneurial approach towards identifying and developing innovative opportunities with high levels of social impact. Internal and external stakeholders should be integrated in the networking process with an open innovation approach coupled with high levels of absorptive capacity (e.g. the ability to assimilate new information in creating new products/services).

\section{Limitations and directions for future research}

The limitations of this research study include:

- No financial analysis was made.

- The scope of the research data was area bound (Pretoria, South Africa).

- The scope of the research data was organisation-specific (DR Church).

- Semi-structured interviews were used as part of a qualitative study (which includes the limitations).

Directions for future research:

- Financial analysis of any social organisation to measure social innovation or social entrepreneurial capabilities.

- Measure social innovation capacity of any other social organisation.

\section{Acknowledgements Competing interests}

The views expressed in this article are that of the authors and not an official position of the institution or funder.

\section{Authors' contributions}

A.A., W.J.S. and W.F.J.v.D. were co-authors and were involved in the research design, while W.J.S. and W.F.J.v.D. were involved in fieldwork.

\section{References}

Baumann, M., 2014, 'Becoming a civil society organisation? Dynamics of immigrant religious communities in civil society and public space', Nordic Journal of Religion and Society $27(2), 113-130$

Bielefeld, W. \& Cleveland, W.S., 2013, 'Defining faith-based organizations and understanding them through research', Nonprofit and Voluntary Sector Quarterly 42(3), 442-467. https://doi.org/10.1177/0899764013484090

Biggeri, M., Testi, E. \& Bellucci, M., 2017, 'Enabling ecosystems for social enterprises and social innovation: A capability approach perspective', Journal of Human Development and Capabilities 18(2), 299-306. https://doi.org/10.1080/1945282 9.2017.1306690

Choi, N. \& Majumdar, S., 2014, 'Social entrepreneurship as an essentially contested concept: Opening a new avenue for systematic future research', Journal of Business Venturing 29(3), 363-376. https://doi.org/10.1016/j.jbusvent.2013.05.001

Corbett, S. \& Fikkert, B., 2014, When helping hurts: How to alleviate poverty without hurting the poor and yourself, Moody Publishers, Chicago.

Creswell, J.W., 2014, Research design: Qualitative, quantitative, and mixed methods approaches, 4th edn., Sage, Thousand Oaks, CA.

Creswell, J.W. \& Poth, C.N., 2017, Qualitative inquiry and research design: Choosing among five approaches, Sage, London, viewed 23 June 2017 , from https://books.
google.co.za/books?hl=en\&|r=\&id=DLbBDQAAQBAJ\&oi=fnd\&pg=PP1\&dq=qualit

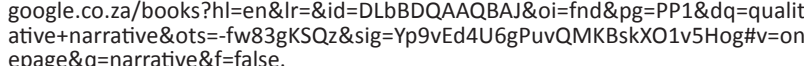
epage \&q=narrative $\& \mathrm{f}=$ false.

Daman, G.C., 2006, Leading the small church: How to develop a transformational ministry, Kregel Publications, Grand Rapids, MI.

De Bassi Padilha, J., Cziulik, C. \& de Camargo Beltrão, P.A., 2017, 'Vectors of innovation definition for application during conceptual design stage of product development
process', Journal of Technology Management \&Innovation 12(1), 49-60. https:// process', Journal of Technology Management
doi.org/10.4067/S0718-27242017000100006

Dees, J.G., 1998, The meaning of social entrepreneurship, viewed 23 June 2017, from http://www.redalmarza.cl/ing/pdf/TheMeaningofsocialEntrepreneurship.pdf.

Drucker, P., 2014, Innovation and entrepreneurship, Routledge, Oxford.

Du Toit, F., Hofmeyr, H., Strauss, P. \& Van der Merwe, J., 2002, Moeisame pad navernuwing, Barnabas, Bloemfontein.

Elliott, J., 2005, Using narrative in social research: Qualitative and quantitative approaches, Sage, London, viewed 23 June 2017, from https://books.google.co. za/books?id=p1DPOH_PNIOC.

Forsman, H., 2011, 'Innovation capacity and innovation development in small enterprises. A comparison between the manufacturing and service sectors', Research Policy 40(5), 739-750. https://doi.org/10.1016/j.respol.2011.02.003

Hirsch-Kreinsen, H., 2008, “'Low-tech” innovations', Industry and Innovation 15(1), 19-43. https://doi.org/10.1080/13662710701850691

Jaiswal, N.K. \& Dhar, R.L., 2015, 'Transformational leadership, innovation climate, creative self-efficacy and employee creativity: A multilevel study', Internationa Journal of Hospitality Management 51, 30-41. https://doi.org/10.1016/j. ijhm.2015.07.002

Khalili, A., 2016, 'Linking transformational leadership, creativity, innovation, and innovation-supportive climate', Management Decision 54(9), 2277-2293. https:// doi.org/10.1108/MD-03-2016-0196

Kickul, J. \& Bacq, S., 2012, Patterns in social entrepreneurship research, Edward Elgar Publishing, Cheltenham.

Kickul, J. \& Lyons, T.S., 2012, Understanding social entrepreneurship: The relentless pursuit of mission in an ever changing world, Routledge, Oxon.

Kirner, E., Kinkel, S. \& Jaeger, A., 2009, 'Innovation paths and the innovation performance of low-technology firms: An empirical analysis of German industry', Research Policy 38(3), 447-458. https://doi.org/10.1016/j.respol.2008.10.011

Li, V., Mitchell, R. \& Boyle, B., 2016, 'The divergent effects of transformational leadership on individual and team innovation', Group \& Organization Management 41(1), 66-97. https://doi.org/10.1177/1059601115573792

Lietz, C.A. \& Zayas, L.E., 2010, 'Evaluating qualitative research for social work practitioners', Advances in Social Work 11(2), 188-202.

Martinez, F., O'Sullivan, P., Smith, M. \& Esposito, M., 2017, 'Perspectives on the role of business in social innovation', Journal of Management Development 36(5), 681695. https://doi.org/10.1108/JMD-10-2016-0212

Mouton, M., 2015, 'Praktiesevaardighedevirtransformasie-leierskap in gemeentes', Kruisgewys, August, p. 7.

Mulgan, G., 2006, 'The process of social innovation', Innovations: Technology, Governance, Globalization 1, 145-162. https://doi.org/10.1162/itgg.2006.1.2.145

NederduitseGereformeerdeKerke, 2015, 2015 Jaarboek van die Nederduitse GereformeerdeKerke, Tydskriftemaatskappy, Wellington.

Newth, J. \& Woods, C., 2014, 'Resistance to social entrepreneurship: How context shapes innovation', Journal of Social Entrepreneurship 5(2), 192-213. https://doi. org/10.1080/19420676.2014.889739 
Niemandt, N., 2007, Nuwedromevirnuwewerklikhede, Lux Verbi, Wellington.

Norman, D.A. \& Verganti, R., 2014, Incremental and radical innovation: Design research vs. technology and meaning change, viewed 01 Apr. 2019, from http:// 0-dx.doi.org.innopac.up.ac.za/10.1162/DESI_a_00250.

Peredo, A.M. \& McLean, M., 2006, 'Social entrepreneurship: A critical review of the concept', Journal of World Business 41(1), 56-65. https://doi.org/10.1016/j. jwb.2005.10.007

Pinelli, T.E., Barclay, R.O. \& Kennedy, J.M., 1996, NASA DoD aerospace knowledge diffusion research project, Report number 45 , The technical communication practices of U.S. aerospace engineers and scientists results of the phase 3 U.S. Aerospace Engineering Educators Survey, DIANE Publishing, Bloomington.

Pirson, M., 2015, Why study social entrepreneurship?, Fordham University Schools of Business Research Paper, (2558208).

Phillips, W., Lee, H., Ghobadian, A., O'Regan, N. \& James, P., 2015, 'Social innovation and social entrepreneurship: A systematic review', Group \& Organization Management 40(3), 428-461. https://doi.org/10.1177/1059601114560063

Schoeman, W.J., 2011, 'Kerkspieël - 'n kritiesebestekopname', Nederduitse GereformeerdeTeologieseTydskrif 52(3), 472-488.

Schoeman, W.J., 2014, 'Agter die syfers is gelowiges, gemeentesen die kerk, 'n praktiesteologieserefleksieoorlidmaatskap', HTS Teologiese Studies/Theological Studies 70(1), 1-10. https://doi.org/10.4102/hts.v70i1.2677

Schultz, R., 2013, Creating good work: The world's leading social entrepreneurs show how to build a healthy economy, Palgrave Macmillan, New York.

Schumpeter, J.A., 1934, The theory of economic development, Harvard University Press, Cambridge, MA.

Scofield, R, 2011, The social entrepreneur's handbook: How to start, build, and run a business that improves the world, McGraw-Hill, New York.
Shaw, E. \& De Bruin, A., 2013, 'Reconsidering capitalism: The promise of social innovation and social entrepreneurship?', International Small Business Journal 31(7), 737-746. https://doi.org/10.1177/0266242613497494

Szeto, E., 2000, 'Innovation capacity: Working towards a mechanism for improving innovation within an inter-organizational network', The TQM Magazine 12(2), 149-158. https://doi.org/10.1108/09544780010318415

Tracey, P. \& Stott, N., 2017, 'Social innovation: A window on alternative ways of organizing and innovating', Innovation 19(1), 51-60. https://doi.org/10.1080/144 79338.2016.1268924

Trelstad, B., 2008, 'Simple measures for social enterprise', Innovations 3(3), 105-118. https://doi.org/10.1162/itgg.2008.3.3.105

Tsai, K.H. and Liao, Y.C., 2017. Innovation capacity and the implementation of ecoinnovation: Toward a contingency perspective. Business Strategy and the Environment, 26(7), pp. 1000-1013.

Tuan, M.T., 2008, Measuring and/or estimating social value creation: Insights into eight integrated cost approaches, Bill \& Melinda Gates Foundation Impact Planning and Improvement, Seattle.

Van Wyk, C., 2015a, 'Gemeentelewedeur die bril van gereeldekerkgangers', Kruisgewys, August, p. 3.

Van Wyk, C., 2015b, 'Waarderingenverwagtings van erediensbywoners', Kruisgewys, August, p. 9.

Writer, S.,2016, How South Africa's super-rich spend their cash vs the poor, viewed 05 April 2017, from https://businesstech.co.za/news/banking/124247/how-southafricas-super-rich-spend-their-cash-vs-the-poor/.

Zahra, S.A., Gedajlovic, E., Neubaum, D.O. \& Shulman, J.M., 2009, 'A typology of social entrepreneurs: Motives, search processes and ethical challenges', Journal of Business Venturing 24, 519-553. https://doi.org/10.1016/j.jbusvent.2008.04.007 